\title{
Persuasive Communication With Successful Healing Post-Extraction of the Patient at the Oral Surgical Clinic And Maxilofacial FKG USU
}

\author{
Azhril Riyandi, Rahmanita Ginting \\ Master of Communication \\ University of Muhammadiyah Sumatera Utara (UMSU) \\ Indonesia \\ rahmanita_ginting@umsu.ac.id
}

\begin{abstract}
This study aims to analyze the persuasive communications of co-assistant student in handle the success of healing post-extraction of patients at the oral surgical clinic and Maxillofacial in FKG USU. Tooth extraction is a process of dental expulsion from the alveolus. There are several things that patients experience after tooth extraction, such as bleeding, pain, edema, and dry socket. This is a complication of the imperfect healing process. The wound healing process is divided into several phases: inflammation phase, proliferation phase, and maturation phase. The theory used in this research is Persuasive Communication, interpersonal communication as well as indications and contradictions after tooth extraction. The method used is descriptive quantitative. The results showed that persuasive communication performed by co-assistant student has good enough success in post dental extraction patient.
\end{abstract}

Keywords-persuasive communication; patient; interpersonal communication

\section{INTRODUCTION}

Communication activities can happen to anyone, such as communication that occurs between doctors with patients. A dentist has an important influence on the health of a patient because a dentist understands more about dentistry than a person who does not learn about dentistry. Tooth extraction is a common practice in dental practice. Any tooth extraction should be done with the correct action and in accordance with the existing procedure. Tooth extraction is a surgical action that includes soft tissue and hard tissue in the oral cavity. the ideal tooth extraction is tooth removal or tooth root intact without pain with as little trauma as possible so that the tooth extraction wound will heal normally and does not cause problems after the tooth extraction [1]. Persuasive communication is a process of communication where there is an attempt to convince others to public act and behave as expected communicator by way of persuading without forced to patients who will do tooth extraction. Communication between the dentist and the patient is competencies that must be dominate by a dentist, this competence that determines the success of a dentist in helping the patient's health problems. A dentist should really understand exactly what the patient's the complaint, therefore communication between the dentist and the patient is needed in this case.

\section{LITERATURE REVIEW}

\section{A. Interpersonal Communication}

"Communication occurs at least a source generating a response to the recipient, through the delivery of a message in a form or symbol, either verbal (word) or nonverbal form, without having to ensure first that the both communicating parties have a same symbol system" 2 .

The Structure and Function of Communication in Society was made by Harold Lasswell, says that a good way to explain communication is to answer the question as follows: Who Says What in Which Channel to Whom with What Effects? The Lasswell paradigm above shows that communication includes five elements namely 1. Communicator, source, sender. 2. Message, 3. channel, media, 4. communicant, communicate, receiver, recipient, 5. effect, impact, influence. So, based on Lasswell's paradigm, communication is the process of delivering messages by communicators to communicants through media that cause certain effects [2].

\section{B. Persuasive Communication}

Persuasive communication is a process of communication where there is an attempt to convince others to public do and behave as expected by the communicator by persuading without forcing it. The principles of persuasive communication are 5 (five) principles, including: 1. persuade for consistency, 2. persuading for small changes, 3. persuade for profit, 4. persuade for the sake of fulfillment, 5. Persuade based on gradual approaches [3][4].

\section{The Healing Process After the Teeth Removal}

Tooth extraction is the process of removing the teeth from the gums, the teeth cannot be treated again. Tooth extraction is also a surgical operation involving the soft tissues of the oral cavity, restricted access by the lips and cheeks. Tooth extraction is an action that involves bone structure, soft tissue in the oral cavity. In the action of tooth extraction sterile actions are required [5][6][7].

The process of wound healing process on tooth extraction is almost the same as the healing in general, it's just that there is 
little special character because it involves bone and soft tissue. The healing stage of the wound after removal is:

- The occurrence of a new cell assembly process on the wound on the 4th day.

- Substitution of blood clot formation into new blood vessels on the 7th day.

- The formation of bone in the wound on the 14th day.

- The formation of soft tissue on the 20th day

- Perfect wound closure on the 28th day.

\section{RESEARCH METHOD}

In this study, it will use the type of qualitative research. Which is a research procedure that produces data, one of them qualitative descriptive form of written of oral words of the people and behavior observed. Qualitative research consists of several types, one of them is a case study. In case study research, a researcher will research by individual or social further [8][9].

Informants in this study as the key informant are students at oral and maxiofacial FKG USU, Lady Indira Azmi (female, 24 years old), M. Adji Wibisono (male, 22 years old), Ulfa Rahmawaty (female, 24 years old), Nita Budiarti (female, 24 years old), Mulia Daniel (female, 26 years old).

Data collection using interviews and documentation studies. Analysis data uses data reduction, data presentation, and draw conclusions. The location of the research was conducted at the Department of Oral and Maxillofacial Surgery of FKG USU Medan for 3 (three) months from December 2017 to February 2018.

\section{RESUlt AND DisCUSSION}

\section{A. Diagnosis of Teeth Removal}

The process of retraction is a formal step before heading to the stage of cure of teeth. The stages of the revocation process begins with the dental medical team, which is the maximofasial FKG USU students doing communication interaction in persuasion. In the world of early dentistry the term was called diagnosis. At this stage, the students are encouraged to create a comfortable interaction with the patient. As Lady said:

"The process of removal of course begins with diagnosis, without diagnosis we do not know the steps, actions, and treatment for patients. Does the patient follow a course of treatment first, or directly in the tooth extraction action. These stages should not be missed because it can be bad for the patient"

Adji also said:

"Diagnosis is a preliminary interaction before extraction. Introduction, and inquiring about the details of the disease history are the first step. This can handle the patient's fears that are likely in some cases to be afraid to pull teeth, for example to children. "
Ulfa said:

"At the stage of the diagnosis is also measuring blood pressure, although teeth can be extraction, but blood pressure is not good will be dangerous for patients. Although we do not directly tell the patient when diagnosing unless the patient asked. When performing a good diagnosis of the interaction stage, the patient will be comfortable and make the treatment process more smoothly. It takes professionalism in interacting."

The professionalism while diagnosing patients is the first step in the interaction and communication of healing teeth extraction. Indirectly, dentist will do stimulation so that patients who are communicant affected for the treatment process went smoothly. The diagnostic stages are very important for healing extraction.

\section{B. Persuasive Communication Process in Teeth Removal}

This step is done after all diagnostic steps are completed. At this stage, verbal communication is not as prominent as in the diagnostic process. However, in some cases there are patients who still feel scared at the time will be injected anesthetic or retraction. As another informant - Nita says:

"In tooth extraction between the dentist and the patient does not talk too much. But sometimes patients love be afraid. Some cases of patients say 'doc, is it pain when do injection?'. A professional dentist is advised to respond appropriately as to say 'if it has been anesthetized, the pain must be gone' that is the interaction in tooth extraction. "

The calmness of the dentist is a non-verbal message that must be shown to the patient and will be considered professional, so that the patient's affection will be felt. As the goal, persuasive communication to change small things. Dentists are required to be able to see the gesture done by the patient, if the patient feels the tension, then the dentist's duty shows calm and certainty in action. As Mulia said:

"When the action, the dentist should be calm with patients. While the patient is afraid, we are encouraged to stop doing the action and start talking this is done so that the patient feels the calm."

Interaction before and after extraction must be persuasive it will be patient feel more trusting and comfortable.

\section{After tooth extraction}

After process of diagnosis and extraction is done, the next stage is to provide continued persuasion for patients to obey the instuction. This goal is pursued for perfect healing. Persuasion is mentioned in the form of instructions to the patients about what to do and not after tooth extraction. As the Lady says:

"We instruct the patient not to suck the wound with the tongue on the wound, do not gargle, and also take the medication. Patients are reminded to keep their oral 
healthy for 6 months, not consuming sweet foods, not consuming hot or cold drinks or foods at the same time. If the patient smokes, encourage quitting. "

For patients with severe tooth decay such as teeth that remain small requires the same handling but more motivation and persuasion. As Adji says:

"For patients whose teeth are gone or no longer have back molars that are useful for chewing food, we suggest to make denture so that patients can eat hard foods such as fruit, meat, etc."

Nita also said:

"We will motivate the patients to take care of their other teeth so that their teeth will not suffer the same fate as teeth that have been extraction. Immediately restoration the tooth that have decay, and routine checks, and immediately consult again if there is a complaint that is felt on the teeth or gums are sick for quick treatment"

Persuasive communication is the optimal step in stimulating the patients to notice the teeth or immediately treat the sick teeth. In the healing phase, each patient has different criteria. There is a submissive, there are pretend to be obedient to the ignorant.

Patients who comply with instruction can be persuasive communication, but for patients who are unconcerned or indifferent to the health of their teeth, persuasion is not enough. There should be an affirmation or fear to the patients with the aim that patients care about the health of their teeth and oral cavity. As the Mulia says:

"If the patient does not follow the instructions, then we will frighten him by saying the wound will not heal and should be operated on. The next stage, we will control by the phone periodically to ask if there are complaints. If no, then the patient is considered to have complied with the instructions given"

The patients come from different ages, but in the oral and maxillofacial surgery clinic FKG USU only handle the age of adults and the elderly. The need for treatment is more directed to the patient or nearest relatives, although not closed to the public. The duty of dental imaging partners is to seek patients for practical obligations as well as to serve patients who are visiting for treatment. The level of persuasive performed will be higher depending on the condition of the teeth experienced by the patient. The more teeth are problematic, persuasion for the oral health of the patient's oral cavity will be increased in order to be free of complaints.

Patients should be persuasive communication more than other patients mostly from the age of 40 years and over. Less teeth and unstable blood pressure must be observed by panitra students. As Ulfa says:
"The age of 40 years and over is a patient who needs special interaction because it sees the need for healthy teeth and attitudes that do not care about his teeth. For that the invitation to care for the teeth periodically often done repeatedly. In contrast to the children who only experienced the first fear once but according to for doing maintenance. "

\section{CONCLUSION}

Good communication between doctor and patient has the potential to help patients' emotions and allow for better identification of patients' needs, perceptions, and expectations.

\section{REFERENCES}

[1] Frgiskos, Oral Surgery. Verlay Berlin Heidelberg: Springer, 2007.

[2] M. Budyatna and L.M. Ganiem, Teori Komunikasi Antarpribadi. Jakarta: Kencana Prenada Media, 2012.

[3] H. Budianto and F. Hamid, Ilmu Komunikasi: Sekarang dan Tantangan Masa Depan. Jakarta: Kencana, 2013.

[4] D. Mulyana, Ilmu Komunikasi Suatu Pengantar. Bandung: Remaja Rosdakarya, 2008.

[5] S. Soemirat, Komunikasi Persuasif. Jakarta: Universitas Terbuka, 2004.

[6] C. Hollins, Levison's TextBook For Dental Nurses. Hongkong: Graphicraft limited, 2013.

[7] L.J. Peterson, E. Ellis and J.R. Hupp, Contemporarry Oral And Maxilofacial Surger. New Delhi India: Mosby, 2003.

[8] H.H. Cangara, Pengantar Ilmu Komunikasi. Jakarta: RajaGrafindo Persada, 2011.

[9] L.J. Moleong, Metodologi Penelitian Kualitatif.. Bandung: Remaja Rosdakarya, 2017. 